\title{
Nutraceutical Effect of Cuetlas (Arsenura armida C.) Edible Insects as Local Food at Ixcaquixtla, Mexico
}

\author{
Virginia Melo-Ruíz ${ }^{1}$, Tomas Quirino-Barreda ${ }^{1}$, Susana Macín-Cabrera ${ }^{2}$, Karina Sánchez-Herrera ${ }^{1}$, Rafael \\ Díaz-García $^{2}$ and Cesar Gazga-Urioste ${ }^{1}$ \\ 1. Department of Biologic Systems, Metropolitan Autonomous University, México City, PC 04960, México \\ 2. Department of Health Care, Metropolitan Autonomous University, México City, PC 04960, México
}

\begin{abstract}
Insect's nutrient composition may provide a good source of macro- and micro-nutrients with nutraceutical functions that could help people from semirural areas, such as Ixcaquixtla, located southeast of the Puebla State, Mexico. The aim of this study was to assess macro- and micro-nutrients in Cuetlas (Arsenura armada C.) larvae and inform local people about the nutraceutical benefits that those insects could provide. Cuetlas larvae samples were collected from Jonote tree on August, 2014 to analyze minerals and macro-nutrient of raw larvae according to AOAC (1995) techniques. Results showed that Cuetlas larvae contained 56.93\% proteins, $14.76 \%$ lipids, $2.95 \%$ minerals, $2.13 \%$ fiber and $23.23 \%$ soluble carbohydrates. Cuetlas larvae have a good amount of proteins, essential macromolecules for human life as well as essential fatty acids that are important sources of fuel for brain cells and in particular for cardiac and skeletal muscle, minerals, not determined individually, which are important for metabolism processes, fiber for digestive processes and soluble carbohydrates as energy source.
\end{abstract}

Key words: Cuetlas, edible insects, nutrition, health, nutraceutical.

\section{Introduction}

Nutraceutical is a term defined as food or food components that provide health or medical benefits, including prevention or treatment of decease in humans [1]. Even though insects are not considered as nutrients for humans, they are directly or indirectly an important piece in nutrition due to the role they play in the staple chain of several animals in terrestrial environment [2]. In this context, entomophagy (insect consumption) has been practiced in Mexico since Prehispanic times, and it provides balanced nutrients to several ethnic groups $[3,4]$. In addition, the selected species of insects play an important role in festivities and are an important source of the requested nutrients for a healthy daily diet [5]. Ixcaquixtla, a semirural village located at the Mixteca area, southeast of Puebla State, Mexico, is an arid zone with a low staple production, but it has several species of edible insects.

Corresponding author: Virginia Melo-Ruíz, Ph.D., research field: under-utilized food.
These edible insects are not consumed by local people as part of their regular diet due to lack of information regarding the nutraceutical benefits that these small animals could provide to human health. Among the variety of insects that can be found in the region, Cuetlas (Arsenura armada C.) in larvae stage of a butterfly, is one of the most appreciated and consumed by inhabitants of Ixcaquixtla, but not due to their nutraceutical functions but as a tradition. These insects belong to the Lepidoptera order, Arsenura armada C. genus/species and can be found at summer season on the Jonote tree (Heliocarpus appendiculatus) and are consumed on its larva stage. The aim of this research was to analyze macro-nutrient composition of Cuetlas that might contribute to the improvement of people's health.

\section{Materials and Methods}

\subsection{Sampling}

Cuetlas (Arsenura armada C.) insects, belonging to the Lepidoptera order and Saturnidae family (Table 1), 
are highly distributed at the Mixteca zone, southeast of the Puebla State (Fig. 1) and can be found on the Jonote tree (Heliocarpus appendiculatus) (Fig. 2). The area was visited previously to get in touch with local people specialized on adequate techniques for insect collection and to determine Cuetla's availability. Insects hatch shows a green color just before raining season, then, when growing, the color changes to dark-brown and thorns appear in their surface which means that they are ready for consumption. Conventional sampling of insects was performed at Ixcaquixtla on August, 2014 directly from Jonote tree. Insects were washed, sun-dried and then thorns were removed by shaking the insects inside a paper bag. Right after, insects were collocated inside of a glass container and transported by land to the Metropolitan Autonomous University to the Laboratory of Bromatology for further nutrients analysis according to AOAC (1995) techniques [6].

\subsection{Determination of Moisture Content}

Sample moisture content was determined by using the direct drying method. Three samples of $10 \mathrm{~g}$ each of Cuetlas were dried in an oven Felisa (Felisa S.A. de C.V, Jalisco, Mexico) at $60{ }^{\circ} \mathrm{C}$ for $24 \mathrm{~h}$. Moisture content was determined according to Eq. (1):

$$
\begin{aligned}
& \text { Moisture }(\%)= \\
& \frac{\left(w_{\text {wet }}+w_{\text {pan }}\right)-\left(w t_{d r y}+w t_{p a n}\right)}{\left(w_{\text {wet }}+w t_{p a n}\right)-w_{p a n}} \times 100
\end{aligned}
$$

where, $\mathrm{wt}_{\mathrm{wet}}=$ weight of the wet sample; $\mathrm{wt}_{\mathrm{dry}}=$ weight of the dry sample; $w_{\mathrm{pan}}=$ weight of the vessel.

Dry samples were powdered in a mortar, then passed through a 30-mesh size. The obtained fine powder was used for further analysis.

\subsection{Determination of Total Minerals}

Ash content was determined using a dry ashing method at $600{ }^{\circ} \mathrm{C}$ in a muffle furnace Felisa (Felisa S.A. de C.V, Jalisco, Mexico) for $6 \mathrm{~h}$ to constant weight, to eliminate the organic matter. Remanent inorganic material was cooled and weighed. Ash solution for determination of mineral composition was then prepared by dissolving the resulting ash in $100 \mathrm{~mL}$ of 1 $\mathrm{N} \mathrm{HCl}$ [7], then $50 \mathrm{~mL}$ was taken for the determination

Table 1 Nomenclature of Cuetlas.

\begin{tabular}{ll}
\hline Class & Cuetlas \\
\hline Order & Lepidoptera \\
Family & Saturnidae \\
Genus & Arsenura \\
Species & Arsenura armida C. \\
Common name & Cuetlas \\
\hline
\end{tabular}

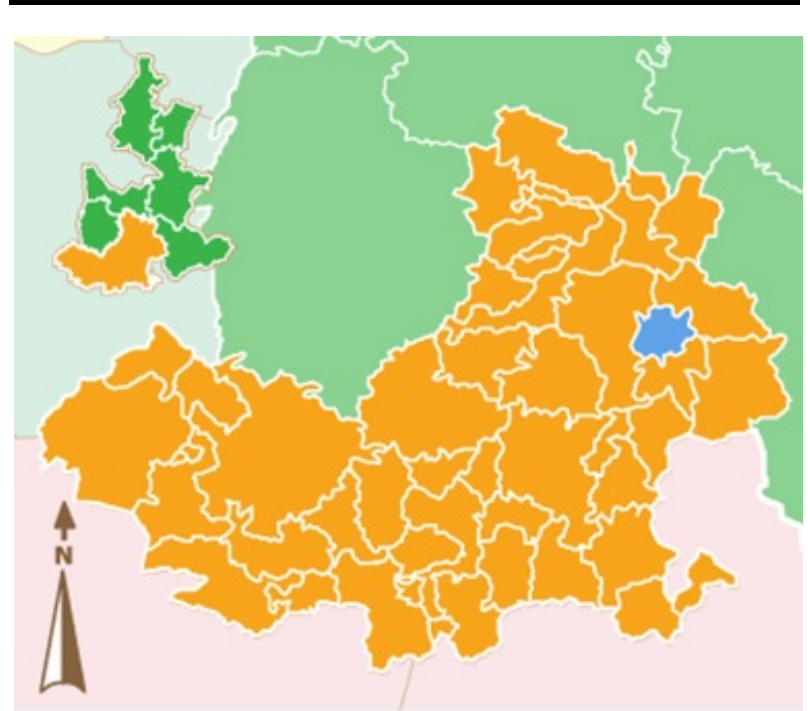

Fig. 1 Ixcaquixtla (blue), located at Mixteca zone (orange), Puebla State (green-orange).

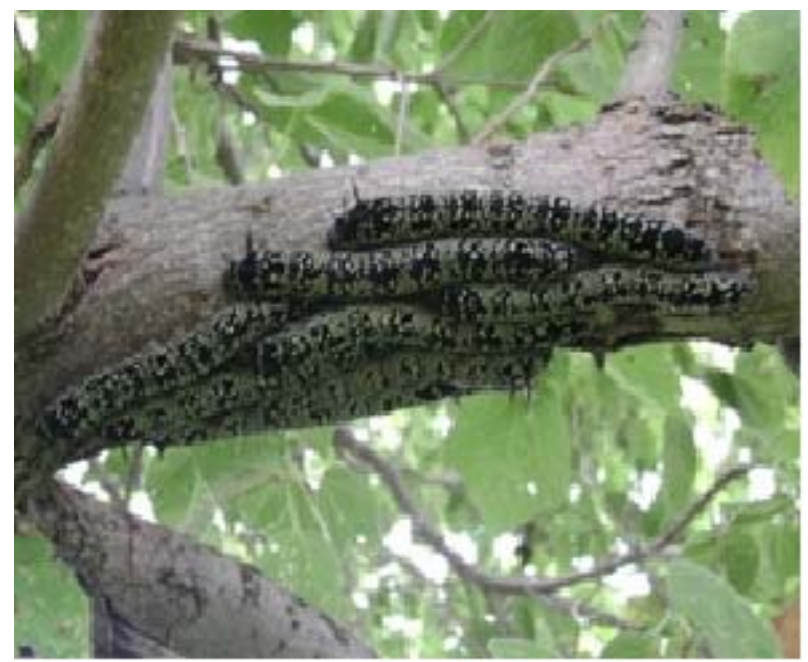

Fig. 2 Image of Cuetlas (Arsenura armada C.) from Jonote tree (Heliocarpus appendiculatus). 
of $\mathrm{Na}, \mathrm{Ca}, \mathrm{K}, \mathrm{Fe}, \mathrm{Zn}$ and $\mathrm{Mg}$ content by atomic absorption spectroscopy [8] using a Varian SpectrAA-250 Plus apparatus, which was calibrated according to the equipment's manual. All samples were analyzed in triplicate. The results are expressed as $\mathrm{g} / 100 \mathrm{~g}$ of sample for ash content and $\mathrm{mg} / 100 \mathrm{~g}$ of sample for each mineral element.

\subsection{Determination of Protein Content}

Sample protein content was determined according to the principle of the Kjeldahl method (AOAC method 945.01) [6]. Sample of $5 \mathrm{~g}$ was digested with $15 \mathrm{~mL}$ of concentrated $\mathrm{H}_{2} \mathrm{SO}_{4}$, using an electrically heated aluminum block digester. The resulting digest was diluted and then made alkaline with $50 \mathrm{~mL} \mathrm{40 \%}$ $\mathrm{NaOH}$. This was followed by rapid steam distillation of ammonia from the diluted digest into $25 \mathrm{~mL}$ of $4 \%$ $\mathrm{H}_{3} \mathrm{BO}_{3}$ for manual titration with $0.2 \mathrm{~N} \mathrm{HCl}$. A convention factor of 6.25 was used to convert the measured nitrogen content to protein content. All samples were analyzed in triplicate and the results were expressed as $\mathrm{g} / 100 \mathrm{~g}$ dry basis of sample [9, 10].

\subsection{Determination of Lipid Content}

Lipid content determination was performed by the semi continuous solvent extraction method (AOAC method 934.01) [6] as follows: sample of $10 \mathrm{~g}$ was extracted with $180 \mathrm{~mL}$ petroleum ether on a Soxhlet apparatus (Sigma-Aldrich, Mexico city, Mexico) at $120{ }^{\circ} \mathrm{C}$ for $6 \mathrm{~h}$. Petroleum ether was removed by evaporation and the lipid residue was weighed. All samples were analyzed in triplicate and the results are expressed as $\mathrm{g} / 100 \mathrm{~g}$ dry basis of sample.

\subsection{Determination of Fiber}

Raw fiber determination of the sample (10 g) was performed by acid hydrolysis with $0.255 \mathrm{~N} \mathrm{H}_{2} \mathrm{SO}_{4}$, followed by alkaline hydrolysis with $0.313 \mathrm{~N} \mathrm{NaOH}$ in a Labconco apparatus (Labconco corporation, Kansas city, USA). Sample was analyzed in triplicate and results expressed as $\mathrm{g} / 100 \mathrm{~g}$ dry basis of sample.

\subsection{Determination of Soluble Carbohydrates}

Carbohydrate content on dry basis was calculated by difference according to Eq. (2):

Soluble carbohydrates $=[100-($ protein + lipids

$$
+ \text { ash }+ \text { raw fiber })]
$$

\section{Results and Discussion}

\subsection{Sampling}

Cuetlas (Arsenura armada C.) are not available all year around and their seasonal availability depends on the biotic and abiotic conditions of the environment. Larvae insects are available mainly in rainy season of summer time. Season availability of Cuetlas (Arsenura armada C.) is shown in Table 2. However, Cuetlas (Arsenura armada C.) can be preserved up to a year by means of different procedures, such as being subjected to hot salty water or toasted for further consumption.

\subsection{Determination of Moisture Content}

As shown in Table 3, Cuetla's (Arsenura armida C.) moisture content is low, being more than $90 \%$ of its weight dry matter, which means that they can be easily stored with low risk of decomposition due to microbial growth.

\subsection{Determination of Total Minerals}

The total amount of minerals found by the dry ashing method was $2.95 \pm 0.6 \mathrm{~g} / 100 \mathrm{~g}$ (Table 4), from which Na 0.55, K 0.693, Ca 0.089, Fe 0.019, Zn 0.020 and $\mathrm{Mg} 1.58 \mathrm{mg} / 100 \mathrm{~g}$ (not all minerals were quantified individually). Most of the times, minerals are not considered as important elements for human diet, due to the low amounts needed for health maintenance. However, these micronutrients are essential for an adequate healthy state. For example, $\mathrm{Na}$ and $\mathrm{K}$ are essential for transmission of electrical impulses along the nerves and for muscle contraction. In a similar way, $\mathrm{Ca}$ also plays an important role in the transmission of electrical signals along nerves and 
Table 2 The availability of Cuetlas (Arsenura armada C.) in 2014.

\begin{tabular}{|c|c|c|c|c|c|}
\hline Month & Feb & Mar & Apr & May & $\mathrm{J}$ \\
\hline Availability - & - & - & - & $\mathrm{x}$ & \\
\hline \multicolumn{6}{|c|}{$\mathrm{X}=$ abundant; $\mathrm{x}=$ low; $-=$ not available. } \\
\hline \multicolumn{6}{|c|}{$\begin{array}{l}\text { Table } 3 \text { Moisture determination of Cuetlas (Arsenura } \\
\text { armada C.). }\end{array}$} \\
\hline Parameter & & Perce & & & \\
\hline Moisture & & $6.58 \%$ & & & \\
\hline Dry sample & & 93.42 & & & \\
\hline
\end{tabular}

Table 4 Macro-nutrients composition of Cuetlas (Arsenura armada C.).

\begin{tabular}{ll}
\hline Nutrient & Content $(\mathrm{g} / 100 \mathrm{~g}$ dry basis $)$ \\
\hline Proteins & $56.93 \pm 0.5$ \\
Lipids & $14.76 \pm 0.8$ \\
Minerals & $2.95 \pm 0.6$ \\
Fiber & $2.13 \pm 0.2$ \\
Soluble carbohydrates & 23.23 \\
\hline
\end{tabular}

All values are mean of triplicate determination.

Protein content $=\mathrm{N}$ determined by kjeldahl $\times 6.25$; soluble carbohydrates obtained by difference according to Eq. (2).

in the brain as well as in muscle contraction. On the other hand, $\mathrm{Mg}$ is an important cofactor for carbohydrates metabolism. Regarding $\mathrm{Zn}$ and Fe, both can be found in blood proteins and are also components of many enzymes. In mammals, including humans, $\mathrm{Fe}$ is an integral part of the blood; a deficiency leads to anemia, a condition that affects many people. In addition, Fe may be found either as $\mathrm{Fe}^{2+}$ or $\mathrm{Fe}^{3+}$, which is the root of its ability to function as an electron transfer agent, transferring electrons to enzymes to perform specific functions. On the other hand, $\mathrm{Zn}$ is believed to be essential in maintaining the protein's three-dimensional structure and its deficiency leads to skin damage and stunted growth $[11,12]$. For all the aforementioned, food mineral composition must be considered.

\subsection{Determination of Protein Content}

Proteins are fundamental components for cellular and organs function, thus the diet must contain not only enough protein and amino acids, but also non-protein energy to permit optimal utilization of dietary protein. Protein energy malnutrition is very common in the world and has severe effects on brain functions. In addition, people with protein energy malnutrition have a reduced immune function and hence are more susceptible to infectious diseases [13]. Protein requirements are about $63 \mathrm{~g} / \mathrm{d}$ for men (body weight $\sim 79 \mathrm{~kg}$ ) and $50 \mathrm{~g} / \mathrm{d}$ for women (body weight $\sim 63 \mathrm{~kg}$ ). In this context, as can be seen in Table 4, protein content of Cuetlas is $56.93 \pm 0.5 \mathrm{~g} / 100 \mathrm{~g}$ dry sample, so it is an important source of this valuable nutrient. And for instance, it might be a good option to fulfill protein requirements for maintaining appropriate metabolic functions for people that can not afford for other protein sources. In addition, excessive protein content may be transformed into carbohydrates by means of gluconeogenesis, acting mainly as an energy source [14].

\subsection{Determination of Lipid Content}

Lipids are required for a diverse array of cellular processes, including structure, function and energy-related roles. In addition, lipids contain more than twice the energy per gram $(9 \mathrm{kcal} / \mathrm{g})$ as does carbohydrates or proteins $(4 \mathrm{kcal} / \mathrm{g})$, which explains why humans preferentially store fat as the primary energy reservoir. Furthermore, dietary lipids are also a source of lipid-soluble vitamins and sterols. It has been recommended that fat should be about 20\%-35\% of the daily food intake [15]. For a 2,000 calorie diet, this represents $56 \mathrm{~g}$ to $78 \mathrm{~g}$ of fat. On the other hand, for a 3,000 calorie diet, this represents about $83 \mathrm{~g}$ to $117 \mathrm{~g}$ of fat [16]. Lipids content of Cuetlas is $14.76 \pm$ $0.8 \mathrm{~g} / 100 \mathrm{~g}$ dry sample, so these insects contain a valuable amount of this important macronutrient that might contribute to fulfill lipids requirements for health maintenance of people living on rural areas. In addition, fatty acid composition of insects appears to be influenced by the plants on which they feed. And it 
has been reported that edible insects are a considerable source of lipids rich in polyunsaturated fatty acids and essential linoleic and $\alpha$-linoleic acids, of which nutritional importance is well recognized, mainly for the healthy development of children [2].

\subsection{Determination of Fiber}

Dietary fiber is generally defined as polysaccharides that can not be digested by human enzymes. Since 1970, Burkitt and Trowel [17] mentioned that the prevalence of heart disease and some cancers was associated to lack of consumption of dietary fiber, therefore adequate intake of dietary fiber is important for human health. In addition, dietary fiber from a wide variety of foods will help to protect from some types of cancers and also aid to normalize blood lipids, thus reduce cardiovascular disease [18]. Also some types of fiber can slow glucose absorption and reduce insulin secretion, which is important for diabetics and nondiabetics as well. These beneficial functions of dietary fiber are essential for a well-balanced diet that will help to minimize some of the most common health problems worldwide. In this context, a product can be defined as a source of fiber, if it contains $3 \mathrm{~g} / 100 \mathrm{~g}$ [19]. For Cuetlas, fiber content is about $2.13 \pm 0.2 \mathrm{~g} / 100 \mathrm{~g}$ of dry sample (Table 4). Thus even low, Cuetlas have fiber that in conjunction with people's regular diet might help to fulfill fiber requirements.

\subsection{Determination of Soluble Carbohydrates}

The carbohydrates group includes some of the most important molecules with multitude of roles involved in human nutrition, such as energy reserves (brain's unique energy source) among others. Cuetlas contain $23.23 \mathrm{~g}$ of carbohydrates/100 g dry sample. In general, it is known that the human diet must be composed of $60 \%$ carbohydrates, so these edible insects contain a low amount of this important nutrient. However, as it has been stated before, due to the high amount of proteins found in Cuetlas, the excess of protein can be transformed into carbohydrates by means of gluconeogenesis.

\section{Conclusions}

Cuetlas larvae are a protein rich food that may help people to obtain these essential macro-molecules. Regarding lipids, important sources of fuel for brain cells and particularly for cardiac and skeletal muscles, the amount found is not high enough to fulfill lipids requirements; however these edible insects can contribute to the enrichment of people's diet. Lastly, fiber and soluble carbohydrates content in Cuetlas are low, but just as happens with lipids, Cuetlas may help, in combination with other sources, to obtain adequate fiber and carbohydrates amounts in order to provide balanced amounts of nutrients that could benefit and improve people's health in Ixcaquixtla and other regions with similar environmental conditions.

\section{References}

[1] DeFelice, S. L. 1995. "The Nutraceutical Revolution: Its Impact on Food Industry R\&D." Trends in Food Science and Technology 6 (2): 59-61.

[2] Van Huis, A., Van Itterbeeck, J., Klunder, H., Mertens, E., Halloran, A., Muir, G., and Vantomme, P. 2013. Edible Insects: Future Prospects for Food and Feed Security. Roma: FAO.

[3] Sahagún, F. B. 1980. Florentine Codex. México: General Archives of the Nation, 247-60. (in Spanish)

[4] Sahagún, F. B. 1988. "Of the Characteristics of Animals, Birds, Fish, Trees, Herbs, Flowers, Metals and Stones and the Colors." In General History of the Things of New Spain. Vol. 2. Mexican: National Council for Culture and Arts, 565-9.

[5] DeFoliart, G. 1999. "Insect as Food: Why the Western Attitude Is Important." Annu. Rev. Entomol. 44: 21-50.

[6] Association of Official Analytical Chemists (AOAC). 1995. Official Methods of Analysis of Association of Official Analytical Chemists, 15th ed.. Washington, DC: AOAC.

[7] Curry, A. S. R., and Kontt, A. R. 1969. "Analyst Flame Atomic Absorption Spectrometry Analytical Methods." Accessed January, 2015. https://www.cdc.gov/niosh/npg/pdfs/P\&cam173.pdf.

[8] Tee, E. S., Rajam, K., Young, S. I., Khor, S. C., and Zakiya, H. O. 1996. Laboratory Procedures in Nutrient Analysis of Foods. Kuala Lumpur, Malasya: Pearson. 
[9] Pearson, D. 1989. Laboratory Technics for the Food Analysis. Zaragoza: Acribia.

[10] Gehrke, C. W., Rexroad, P. R., Schisla, R. M., Absheer, J. S., and Zumwalt, R. W. 1987. "Quantitative Analysis of Cysteine, Methionine, Lysine and Nine Other Amino Acids by a Single Oxidation-Four Hour Hydrolysis Method." J. Assoc. Off. Anal. Chem. 70 (1): 171-4.

[11] Reilly, C. 2006. The Nutrition Trace Elements. Oxford, UK: Blackwell Publishing Ltd..

[12] Crabb, E., and Moore, E., eds. 2010. Metals and Life, 1st ed.. Cambridge, UK: Royal Society of Chemistry.

[13] Pencharz, P. B. 2012. "Protein and Amino Acids." In Present Knowledge in Nutrition, 10th ed., edited by Erdman, J. W., Macdonald, I. A., and Zeisel, S. H. Iowa, USA: Wiley-Blackwell, 69-82.

[14] Mahan, L. K., and Escott-Stump, S. 1998. Nutrition and Diet Therapy of Krause, 9th ed.. Mexico: McGrawHill. (in Spanish).

[15] Jones, P. J. H., and Papamandjaris, A. A. 2012. "Lipids:
Cellular Metabolism.” In Present Knowledge in Nutrition, 10th ed., edited by Erdman, J. W., Macdonald, I. A., and Zeisel, S. H. Iowa, USA: Wiley-Blackwell, 132-48.

[16] Lichtenstein, A. H., and Jones, P. J. H. 2012. "Lipids: Absorption and Transport." In Present Knowledge in Nutrition, 10th ed., edited by Erdman, J. W., Macdonald, I. A., and Zeisel, S. H. Iowa, USA: Wiley-Blackwell, 118-31.

[17] Burkitt, D. P., and Trowel, H. C. 1975. Refined Carbohydrate Foods and Disease. London, England: Academic Press.

[18] Vahouny, G. V., and Kritchevsky, D., eds. 1986. Dietary Fiber: Basic and Clinical Aspects. New York, USA: Plenum Press.

[19] Johnson, I. T. 2012. "Dietary Fiber." In Present Knowledge in Nutrition, 10th ed., edited by Erdman, J. W., Macdonald, I. A., and Zeisel, S. H. Iowa, USA: Wiley-Blackwell, 97-117. 